\title{
Importance of Location Classification using Rough Set Approach for the Development of Business Establishment
}

\author{
Sujogya Mishra \\ Research scholar, \\ Utkal University \\ Bhubaneswar-751004, \\ India
}

\author{
Shakti Prasad \\ Mohanty \\ Department of \\ Mathematics \\ College of Engineering \\ and Technology \\ Bhubaneswar-751003, \\ India
}

\author{
Sateesh Kumar \\ Pradhan \\ Department of \\ Computer Science \\ Utkal University \\ Bhubaneswar-751004, \\ India
}

\author{
Radhanath Hota \\ Department of \\ Computer Science \\ College of Basic \\ Science \& Humanities \\ OUAT, Bhubaneswar- \\ 751003, India
}

\begin{abstract}
In the recent age business establishments are basically needs scientific approach to attain success. In this paper we consider different forms of location and using rough set we develop an algorithm to find best form of location required to attain success in a particular business.
\end{abstract}

\section{Keywords}

Rough Set Theory, business data, Granular computing, Data mining

\section{INTRODUCTION}

The demand for business and wide use of modern technology for the development of business produces huge data in many forms. The data generation not only put dilemma in the mind of the user but also it creates obstacle for user to derive the exact result. This has created an obvious challenge for the researchers in the development of reduce data set and to derive the exact data for a particular application. The application of rough set theory has a prime role to play for knowledge discovery in data base(s).The ever increasing field of knowledge discovery (KD) that helps in derivation of hidden information from large database[3]. Data mining is also considered as essential tool in this knowledge discovery process which uses techniques from different disciplines ranging from machine learning, statistics information sciences, database, visualization ([4][12]). Further, prediction of business failure needs a systematic and scientific study. The first approach to predict business failure started in 1995 by Zopounidis( [24]-[26]). The methods proposed are the "five C" methods, the "LAPP" method, and the "credit-men" method. Then, financial ratios methodology was developed for business failure prediction problem. This approach gives rise the methods for business failure prediction based on multivariate statistical analysis (Altman ([13]-[15]), Beaver[17], Courtis[18]). Frydman et al[19] first employed recursive et al[16], multi-factor model by Vermeulen et al[23] are also other methods developed for business failure prediction.

This paper presents a methodology for business success by reduction of attributes using rough set theory. Portioning, while Gupta et al[20] use mathematical programming as an alternative to multivariate discriminate analysis for business failure prediction problem. Other methods used were survival analysis by Luoma, Laitinenl[21] which is a tool for company failure prediction, expert systems by Messier and Hansen[22], neural network by Altman

\section{PRILIMINARIES}

\subsection{Rough set}

Rough set theory as introduced by Z. Pawlak[2] is an extension of conventional set theory that support approximations in decision making.

\subsubsection{Approximation Space}

An Approximation space is a pair $(\mathrm{U}, \mathrm{R})$ where $\mathrm{U}$ is a nonempty finite set called the universe $\mathrm{R}$ is an equivalence relation defined on $\mathrm{U}$.

\subsubsection{Information System}

An information system is a pair $\mathrm{S}=(\mathrm{U}, \mathrm{A})$, where $\mathrm{U}$ is the non-empty finite set called the universe, $\mathrm{A}$ is the non-empty finite set of attributes

\subsubsection{Decision Table:}

A decision table is a special case of information systems

$\mathrm{S}=(\mathrm{U}, \mathrm{A}=\mathrm{C} \mathrm{U}\{\mathrm{d}\})$, where $\mathrm{d}$ is not in $\mathrm{C}$.

Attributes in $\mathrm{C}$ are called conditional attributes and $\mathrm{d}$ is a designated attribute called the decision attribute.

\subsubsection{Approximations of Sets}

Let $\mathrm{S}=(\mathrm{U}, \mathrm{R})$ be an approximation space and $\mathrm{X}$ be a subset of $\mathrm{U}$.

The lower approximation of $\mathrm{X}$ by $\mathrm{R}$ in $\mathrm{S}$ is defined as

$$
\underline{\mathrm{RX}}=\{\mathrm{e} \varepsilon \mathrm{U} \mid[\mathrm{e}] \varepsilon \mathrm{X}\} \text { and }
$$

The upper approximation of $\mathrm{X}$ by $\mathrm{R}$ in $\mathrm{S}$ is defined as

$$
\bar{R} X=\{e \in U /[e] \cap X \neq \phi\}
$$

where [e] denotes the equivalence class containing e.

A subset $\mathrm{X}$ of $\mathrm{U}$ is said to be $\mathrm{R}$-definable in $\mathrm{S}$ if and only if

$\bar{R} \mathrm{X}=\mathrm{RX}$

A set $\mathrm{X}$ is rough in $\mathrm{S}$ if its boundary set is nonempty. 


\subsection{Dependency of Attributes}

Let $\mathrm{C}$ and $\mathrm{D}$ be subsets of $\mathrm{A}$. We say that $\mathrm{D}$ depends on $\mathrm{C}$ in a degree $\mathrm{k}(0 \leqq \mathrm{k} \leqq 1)$ denoted by $\mathrm{C} \rightarrow \mathrm{k} \mathrm{D}$ if

$k=\gamma(C, D)=\frac{\operatorname{IPOS}_{C}(D) \mathrm{I}}{\mathrm{I} U \mathrm{I}}$

where $\operatorname{POS}_{C}(D)=\underset{X \in U / D}{\cup} \underline{C}(X)$ called a positive region of the

partition $U$ / D with respect to $C$, which is the set of all elements of $\mathrm{U}$ that can be uniquely classified to blocks of the partition U / D

If $k=1$ we say that $D$ depends totally on $C$.

If $\mathrm{k}<1$ we say that $\mathrm{D}$ depends partially (in a degree $\mathrm{k}$ ) on $\mathrm{C}$

\subsection{Dispensable and Indispensable Attributes}

Let $\mathrm{S}=(\mathrm{U}, \mathrm{A}=\mathrm{C} \vee \mathrm{D})$ be a decision table.Let $\mathrm{c}$ be an attribute in C.Attribute $\mathrm{c}$ is dispensable in $\mathrm{S}$ if $\operatorname{POSC}(\mathrm{D})=$ $\operatorname{POS}(\mathrm{C}-\{\mathrm{c}\})(\mathrm{D})$ otherwise, $\mathrm{c}$ is indispensable.A decision table $\mathrm{S}$ is independent if all attributes in $\mathrm{C}$ are indispensable.

Rough Set Attribute Reduction (RSAR) provides a filter based tool by which knowledge may be extracted from a domain in a concise way; retaining the information content whilst reducing the amount of knowledge involved

\subsection{Reduct and Core}

Let $\mathrm{S}=(\mathrm{U}, \mathrm{A}=\mathrm{C} \mathrm{U} \mathrm{D})$ be a decision table.A subset $\mathrm{R}$ of $\mathrm{C}$ is a reduct of $\mathrm{C}$, if $\operatorname{POSR}(\mathrm{D})=\operatorname{POSC}(\mathrm{D})$ and $\mathrm{S}^{\prime}=(\mathrm{U}$, RUD) is independent,ie., all attributes in $\mathrm{R}$ are indispensible in $\mathrm{S}^{\prime}$. Core of $\mathrm{C}$ is the set of attributes shared by all reducts of $\mathrm{C}$. $\operatorname{CORE}(\mathrm{C})=\cap \operatorname{RED}(\mathrm{C})$ where, $\operatorname{RED}(\mathrm{C})$ is the set of all reducts of C.The reduct is often used in the attribute selection process to eliminate redundant attributes towards decision making.

\subsection{Correlation}

Correlation define as a mutual relationship or connection between two or more things. The quantity $r$, called the linear correlation coefficient, measures the strength and the direction of a linear relationship between two variables. The linear correlation coefficient is sometimes referred to as the Pearson product moment correlation coefficient in honor of its developer Karl Pearson. The mathematical formula for its coefficient given by the formula

$$
r=\frac{n \sum x y-\left(\sum x\right)\left(\sum y\right)}{\sqrt{n\left(\sum x^{2}\right)-\left(\sum x\right)^{2}} \sqrt{n\left(\sum y^{2}\right)-\left(\sum y\right)^{2}}}
$$

\subsection{Goodness of fit}

The goodness of fit of a statistical model describes how well it fits a set of observations. Measures of goodness of fit typically summarize the discrepancy between observed values and the values expected under the model in question

\subsection{Chi squared distribution}

A chi-squared test, also referred to as $\chi^{2}$ test, is any statistical hypothesis test in which the sampling distribution of the test statistic is a chi squared distribution when the null hypothesis is true. Also considered a chi-squared test is a test in which this is asymptotically true, meaning that the sampling distribution (if the null hypothesis is true) can be made to approximate a chi-squared distribution as closely as desired by making the sample size large enough. The chi-square (I) test is used to determine whether there is a significant difference between the expected frequencies and the observed frequencies in one or more categories. Do the numbers of individuals or objects that fall in each category differ significantly from the number you would expect? Is this difference between the expected and observed due to sampling variation, or is it a real difference

\subsection{Further analysis of chi square test}

Basic properties of chi squared goodness fit is that it is non symmetric in nature .How ever if the degrees of hypothesis freedom increased it appears to be to be more symmetrical .It is right tailed one sided test. All expectation in chi squared test is greater than 1.EI=npi where $\mathrm{n}$ is the number samples considered pi is the probability of ith occurrence .Data selected at random there are two hypothesis null hypothesis and alternate hypothesis null denoted by $\mathrm{HO}$ alternate hypothesis denoted by $\mathrm{H} 1$. $\mathrm{HO}$ is the claim does follow the hypothesis and $\mathrm{H} 1$ is the claim does not follow the hypothesis here $\mathrm{H} 1$ is called the alternate hypothesis to H0.If the test value found out to be $\mathrm{K}$ then $\mathrm{K}$ can be calculated by the formula $\mathrm{K}=\sum(\mathrm{OI}-\mathrm{EI}) 2 /$ EI. Choice of significance level always satisfies type 1 error.

\subsection{Different types of error}

1. Type 1 error-Rejecting a hypothesis even though it is true

2. Type 2 error-Accepting the hypothesis when it is false

3. Type 3 error-Rejecting a hypothesis correctly for wrong reason

\section{BASIC IDEA}

The basic idea for the proposed work is born from the general business systems. We at first consider 1000 samples, and using five conditional attributes such as urban location, location with five star accommodation, location with aviation facilities, location without aviation facilities, location with aviation facilities along with five star accommodation and two decision attributes such as failure, and success. Here we properly define the urban location means location with township facilities. we mean we are emphasized on quality improvement by which improve the stability of the product .For this purpose we initially we consider 1000 samples then by using correlation technique, only 20 samples are selected which appears to be dissimilar initially then by applying rough set concept we reduced the number of attributes (from the location view point ).

\section{DATA REDUCTION}

As the volume of data is increasing day by day, it is very difficult to find which type of location is important for business establishment and which are not that important and can be neglected. The aim of data reduction is to find the relevant attributes (location) that have all essential information of the data set. The process is illustrated through the following 20 samples by using the rough set theory. For this paper we consider the conditional attributes that described in section 3 which can be applied to all types of business house? Further simplification we rename the 
five attributes such urban location as a1, location with five star accommodation as a2, location with aviation facilities as a3, location without aviation facilities a4, location with aviation facilities along with five star accommodation as a5. Conditional attribute values are consider as available, Partially available, Not available renamed as b1, b2 and b3 respectively decision attribute $\mathrm{d}$ are considered as success and failure renamed as $\mathrm{c} 1$ and $\mathrm{c} 2$ respectively. Data are collected from various sources. To start with we consider initial table which is generated from 20 samples which we get by the method of correlation techniques.

Table-1:

\begin{tabular}{|c|c|c|c|c|c|c|}
\hline $\mathrm{E}$ & $\mathrm{a}_{1}$ & $\mathrm{a}_{2}$ & $\mathrm{a}_{3}$ & $a_{4}$ & $a_{5}$ & $\mathrm{~d}$ \\
\hline $\mathrm{E}_{1}$ & $\mathrm{~b}_{2}$ & $\mathrm{~b}_{2}$ & $b_{1}$ & $b_{1}$ & $b_{1}$ & $\mathrm{c}_{1}$ \\
\hline $\mathrm{E}_{2}$ & $\mathrm{~b}_{2}$ & $\mathrm{~b}_{2}$ & $\mathrm{~b}_{1}$ & $\mathrm{~b}_{3}$ & $b_{3}$ & $\mathrm{c}_{1}$ \\
\hline $\mathrm{E}_{3}$ & $\mathrm{~b}_{1}$ & $\mathrm{~b}_{2}$ & $\mathrm{~b}_{2}$ & $\mathrm{~b}_{3}$ & $\mathrm{~b}_{3}$ & $\mathrm{c}_{2}$ \\
\hline $\mathrm{E}_{4}$ & $b_{1}$ & $\mathrm{~b}_{2}$ & $\mathrm{~b}_{2}$ & $\mathrm{~b}_{3}$ & $b_{3}$ & $\mathrm{c}_{1}$ \\
\hline $\mathrm{E}_{5}$ & $b_{3}$ & $b_{3}$ & $\mathrm{~b}_{3}$ & $b_{3}$ & $\mathrm{~b}_{2}$ & $\mathrm{c}_{2}$ \\
\hline $\mathrm{E}_{6}$ & $b_{1}$ & $\mathrm{~b}_{2}$ & $\mathrm{~b}_{2}$ & $\mathrm{~b}_{2}$ & $b_{2}$ & $\mathrm{c}_{1}$ \\
\hline $\mathrm{E}_{7}$ & $\mathrm{~b}_{2}$ & $\mathrm{~b}_{2}$ & $\mathrm{~b}_{2}$ & $b_{2}$ & $b_{2}$ & $\mathrm{c}_{1}$ \\
\hline $\mathrm{E}_{8}$ & $\mathrm{~b}_{1}$ & $\mathrm{~b}_{1}$ & $\mathrm{~b}_{1}$ & $b_{1}$ & $b_{1}$ & $\mathrm{c}_{2}$ \\
\hline $\mathrm{E}_{9}$ & $\mathrm{~b}_{1}$ & $\mathrm{~b}_{2}$ & $\mathrm{~b}_{2}$ & $\mathrm{~b}_{3}$ & $\mathrm{~b}_{3}$ & $\mathrm{c}_{1}$ \\
\hline $\mathrm{E}_{1}$ & $\mathrm{~b}_{1}$ & $\mathrm{~b}_{2}$ & $\mathrm{~b}_{2}$ & $\mathrm{~b}_{2}$ & $b_{2}$ & $\mathrm{c}_{2}$ \\
\hline $\mathrm{E}_{1}$ & $\mathrm{~b}_{2}$ & $b_{3}$ & $b_{3}$ & $b_{3}$ & $\mathrm{~b}_{3}$ & $\mathrm{c}_{2}$ \\
\hline $\mathrm{E}_{1}$ & $\mathrm{~b}_{1}$ & $\mathrm{~b}_{2}$ & $\mathrm{~b}_{3}$ & $b_{1}$ & $b_{2}$ & $\mathrm{c}_{1}$ \\
\hline $\mathrm{E}_{1}$ & $b_{3}$ & $\mathrm{~b}_{2}$ & $\mathrm{~b}_{2}$ & $\mathrm{~b}_{2}$ & $\mathrm{~b}_{1}$ & $\mathrm{c}_{2}$ \\
\hline $\mathrm{E}_{1}$ & $b_{3}$ & $\mathrm{~b}_{3}$ & $b_{3}$ & $b_{3}$ & $b_{3}$ & $\mathrm{c}_{2}$ \\
\hline $\mathrm{E}_{1}$ & $\mathrm{~b}_{2}$ & $b_{1}$ & $\mathrm{~b}_{1}$ & $b_{1}$ & $b_{1}$ & $\mathrm{c}_{1}$ \\
\hline $\mathrm{E}_{1}$ & $\mathrm{~b}_{1}$ & $\mathrm{~b}_{1}$ & $\mathrm{~b}_{1}$ & $\mathrm{~b}_{1}$ & $b_{1}$ & $\mathrm{c}_{1}$ \\
\hline $\mathrm{E}_{1}$ & $b_{1}$ & $b_{3}$ & $\mathrm{~b}_{2}$ & $\mathrm{~b}_{2}$ & $b_{3}$ & $\mathrm{c}_{2}$ \\
\hline $\mathrm{E}_{1}$ & $\mathrm{~b}_{1}$ & $\mathrm{~b}_{2}$ & $\mathrm{~b}_{2}$ & $b_{3}$ & $b_{2}$ & $\mathrm{c}_{1}$ \\
\hline $\mathrm{E}_{1}$ & $\mathrm{~b}_{1}$ & $b_{3}$ & $\mathrm{~b}_{1}$ & $b_{3}$ & $b_{1}$ & $\mathrm{c}_{2}$ \\
\hline $\mathrm{E}_{2}$ & $\mathrm{~b}_{2}$ & $\mathrm{~b}_{2}$ & $\mathrm{~b}_{2}$ & $b_{3}$ & $b_{3}$ & $\mathrm{c}_{1}$ \\
\hline
\end{tabular}

The decision table -1 , takes the initial values before finding the reduct looking at the data table it is found that entities E3,E4, ambiguous in nature so both E3,E4 remove from the relational table -1 to produce the new table as our Table-2
Table -2

\begin{tabular}{|l|l|l|l|l|l|l|}
\hline$E$ & $a_{1}$ & $a_{2}$ & $a_{3}$ & $a_{4}$ & $a_{5}$ & $d$ \\
\hline$E_{1}$ & $b_{2}$ & $b_{2}$ & $b_{1}$ & $b_{1}$ & $b_{1}$ & $c_{1}$ \\
\hline$E_{2}$ & $b_{2}$ & $b_{2}$ & $b_{1}$ & $b_{3}$ & $b_{3}$ & $c_{1}$ \\
\hline$E_{5}$ & $b_{2}$ & $b_{1}$ & $b_{2}$ & $b_{3}$ & $b_{2}$ & $c_{2}$ \\
\hline$E_{6}$ & $b_{1}$ & $b_{2}$ & $b_{2}$ & $b_{2}$ & $b_{2}$ & $c_{1}$ \\
\hline$E_{7}$ & $b_{2}$ & $b_{2}$ & $b_{2}$ & $b_{2}$ & $b_{2}$ & $c_{1}$ \\
\hline$E_{8}$ & $b_{1}$ & $b_{1}$ & $b_{1}$ & $b_{1}$ & $b_{1}$ & $c_{1}$ \\
\hline$E_{9}$ & $b_{1}$ & $b_{2}$ & $b_{2}$ & $b_{3}$ & $b_{3}$ & $c_{1}$ \\
\hline $\begin{array}{l}E_{1} \\
0\end{array}$ & $b_{1}$ & $b_{2}$ & $b_{2}$ & $b_{2}$ & $b_{2}$ & $c_{2}$ \\
\hline $\begin{array}{l}E_{1} \\
1\end{array}$ & $b_{2}$ & $b_{2}$ & $b_{1}$ & $b_{3}$ & $b_{3}$ & $c_{2}$ \\
\hline $\begin{array}{l}E_{1} \\
2\end{array}$ & $b_{1}$ & $b_{2}$ & $b_{1}$ & $b_{1}$ & $b_{2}$ & $c_{1}$ \\
\hline $\begin{array}{l}E_{1} \\
3\end{array}$ & $b_{1}$ & $b_{2}$ & $b_{2}$ & $b_{2}$ & $b_{1}$ & $c_{2}$ \\
\hline $\begin{array}{l}E_{1} \\
4\end{array}$ & $b_{2}$ & $b_{2}$ & $b_{2}$ & $b_{3}$ & $b_{3}$ & $c_{2}$ \\
\hline $\begin{array}{l}E_{1} \\
5\end{array}$ & $b_{2}$ & $b_{1}$ & $b_{1}$ & $b_{1}$ & $b_{1}$ & $c_{1}$ \\
\hline $\begin{array}{l}E_{1} \\
6\end{array}$ & $b_{1}$ & $b_{1}$ & $b_{1}$ & $b_{1}$ & $b_{1}$ & $c_{1}$ \\
\hline $\begin{array}{l}E_{1} \\
7\end{array}$ & $b_{1}$ & $b_{2}$ & $b_{2}$ & $b_{2}$ & $b_{3}$ & $c_{2}$ \\
\hline $\begin{array}{l}E_{1} \\
8\end{array}$ & $b_{1}$ & $b_{2}$ & $b_{2}$ & $b_{3}$ & $b_{2}$ & $c_{2}$ \\
\hline$E_{1}$ & $b_{1}$ & $b_{2}$ & $b_{1}$ & $b_{3}$ & $b_{1}$ & $c_{2}$ \\
\hline$E_{2}$ & $b_{2}$ & $b_{3}$ & $b_{3}$ & $c_{1}$ \\
\hline
\end{tabular}

\subsection{Indiscernibility relation}

'Indiscernibility Relation' is the relation between two or more objects where all the values are identical in relation to a subset of considered attributes.

\subsection{Approximation}

The starting point of rough set theory is the indiscernibility relation, generated by information concerning objects of interest. The indiscernibility relation is intended to express the fact that due to the lack of knowledge it is unable to discern some objects employing the available information Approximations is also other an important concept in Rough Sets Theory, being associated with the meaning of the approximations topological operations (Wu et al., 2004). The lower and the upper approximations of a set are interior and closure operations in a topology generated by the indiscernibility relation. Below is presented and described the types of approximations that are used in Rough Sets Theory. 


\section{a. Lower Approximation}

Lower Approximation is a description of the domain objects that are known with certainty to belong to the subset of interest.The Lower Approximation Set of a set $\mathrm{X}$, with regard to $\mathrm{R}$ is the set of all objects, which can be classified with $\mathrm{X}$ regarding $\mathrm{R}$, that is denoted as $\mathrm{R}_{\mathrm{L}}$

b. Upper Approximation- Upper Approximation is a description of the objects that possibly belong to the subset of interest. The Upper Approximation Set of a set X regarding $\mathrm{R}$ is the set of all of objects which can be possibly classified with $\mathrm{X}$ regarding $\mathrm{R}$. Denoted as $\mathrm{R}_{\mathrm{U}}$.

Boundary Region is description of the objects that of a set $\mathrm{X}$ regarding $\mathrm{R}$ is the set of all the objects, which cannot be classified neither as $\mathrm{X}$ nor $-\mathrm{X}$ regarding $\mathrm{R}$. If the boundary region $X=\phi$ then the set is considered "Crisp", that is, exact in relation to $\mathrm{R}$; otherwise, if the boundary region is a set $\mathbf{X} \neq \phi$ the set $X$ "Rough" is considered. In that the boundary region is $B R=R_{U}-R_{L}$.

The lower and the upper approximations of a set are interior and closure operations in a topology generated by a indiscernibility relation. In discernibility according to decision attributes in this case has divided in to two groups

One group consist of all positive case and other one all negative cases

$E_{(\text {Success })}=\left\{\quad E_{1}, \quad E_{2}, \quad E_{6}, \quad E_{7}, \quad E_{8}, \quad E_{9} \quad, E_{12}, \quad E_{15}\right.$, $\left.\mathrm{E}_{16}, \mathrm{E}_{20}\right\} \ldots(1)$

$\left.\mathrm{E}_{(\text {Failure }}\right)=\left\{\mathrm{E}_{5}, \mathrm{E}_{10}, \mathrm{E}_{11}, \mathrm{E}_{13}, \mathrm{E}_{14}, \mathrm{E}_{17}, \mathrm{E}_{18},\right\}$

Here in this case lower approximation for Success represented by the first equation and lower approximation for failure represented by the Second equation now we find the entities which are falls into different groups to generate different equivalence classes as follows. Another notation in this case we follows as partially available denoted as $\mathrm{p}$ available, not available denoted as $\mathrm{n}$ available

$$
\begin{aligned}
& E\left(a_{1}\right)_{\text {available }}=\left\{E_{6}, E_{8}, E_{9}, E_{10}, E_{12}, E_{16}, E_{17}, E_{18}, E_{19}\right\} \\
& E\left(a_{1}\right)_{\text {pavilble }}=\left\{E_{1}, E_{2}, E_{7}, E_{11}, E_{15}, E_{20}\right\} \\
& E\left(a_{1}\right)_{\text {navailable }}==\left\{E_{5}, E_{13}, E_{14}\right\}, E\left(a_{2}\right)_{\text {high }}=\left\{E_{8}, E_{15},\right. \\
& \left.E_{16}\right\} \\
& E\left(a_{2}\right)_{\text {pavailable }}=\left\{E_{1}, E_{2}, E_{6}, E_{7}, E_{9}, E_{10}, E_{12}, E_{13}, E_{18}, E_{20}\right\} \\
& E\left(a_{2}\right)_{\text {navailable }}=\left\{E_{1}, E_{8}, E_{12}, E_{15}, E_{16}\right\} \\
& E\left(a_{3}\right)_{\text {available }}=\left\{E_{1}, E_{8}, E_{12}, E_{15}, E_{16}\right\} \\
& E\left(a_{3}\right)_{\text {pavailable }}=\left\{E_{6}, E_{7}, E_{10}, E_{13}, E_{17}\right\} \\
& E\left(a_{3}\right)_{\text {navailable }}=\{ \\
& \left.E_{5}, E_{11}, E_{12}, E_{14}\right\} \\
& E\left(a_{4}\right)_{\text {pavailable }}=\left\{E_{11}, E_{12}, E_{14}\right\} \\
& E\left(a_{4}\right)_{\text {navailable }}=\left\{E_{12}, E_{6}, E_{7}, E_{10}, E_{13}, E_{16}\right\} \\
& E\left(a_{5}\right)_{\text {availablable }}=\{ \\
& E\left(a_{5}\right)_{\text {pavailable }}=\left\{E_{1}, E_{8}, E_{13}, E_{6}, E_{7}, E_{15}, E_{16}, E_{19}\right\}
\end{aligned}
$$

$E(a 5)_{\text {navailable }}=\left\{E_{2}, E_{9}, E_{11}, E_{14}, E_{17}, E_{20}\right\}$ Next, we find the combination of two attributes each to generate the reduct such combinations are $\mathrm{E}\left(\mathrm{a}_{1}, \mathrm{a}_{2}\right), \mathrm{E}\left(\mathrm{a}_{1}, \mathrm{a}_{3}\right)$, $\mathrm{E}\left(\mathrm{a}_{1}, \mathrm{a}_{4}\right), \quad \mathrm{E}\left(\mathrm{a}_{1}, \mathrm{a}_{5}\right) \quad \mathrm{E}\left(\mathrm{a}_{1}, \mathrm{a}_{2}\right)_{\text {available }}=\left\{\mathrm{E}_{8}, \mathrm{E}_{16}\right\}$ $E\left(a_{1}, a_{2}\right)_{\text {pavailable }}=\left\{E_{1}, E_{2}, E_{7}, E_{20}\right\}$

$\mathrm{E}\left(\mathrm{a}_{1}, \mathrm{a}_{2}\right)_{\text {navailable }}=\left\{\mathrm{E}_{3}, \mathrm{E}_{14}\right\} \quad \mathrm{E}\left(\mathrm{a}_{1}, \mathrm{a}_{3}\right)_{\text {available }}=\left\{\mathrm{E}_{8}, \mathrm{E}_{16}, \mathrm{E}_{19}\right\}$ $\mathrm{E}\left(\mathrm{a}_{1}, \mathrm{a}_{3}\right)_{\text {pavailable }}=\left\{\mathrm{E}_{7}, \mathrm{E}_{20}\right\}$

$\mathrm{E}\left(\mathrm{a}_{1}, \mathrm{a}_{3}\right)_{\text {navailable }}=\left\{\mathrm{E}_{5}, \mathrm{E}_{14}\right\} \quad \mathrm{E}\left(\mathrm{a}_{1}, \mathrm{a}_{4}\right)_{\text {available }}=\left\{\mathrm{E}_{8}, \mathrm{E}_{12}, \mathrm{E}_{16}\right\}$ $\mathrm{E}\left(\mathrm{a}_{1}, \mathrm{a}_{4}\right)_{\text {pavailable }}=\left\{\mathrm{E}_{7}\right\} \quad \mathrm{E}\left(\mathrm{a}_{1}, \mathrm{a}_{4}\right)_{\text {navailable }}=\left\{\mathrm{E}_{5}, \mathrm{E}_{14}\right\}$ $\mathrm{E}\left(\mathrm{a}_{1}, \mathrm{a}_{5}\right)_{\text {available }}=\left\{\mathrm{E}_{8}, \mathrm{E}_{12}, \mathrm{E}_{16}\right\} \quad \mathrm{E}\left(\mathrm{a}_{1}, \mathrm{a}_{5}\right)_{\text {pavailable }}=\left\{\mathrm{E}_{7}\right\}$ $E\left(a_{1}, a_{5}\right)_{\text {navailable }}=\left\{E_{14}\right\}$

$\mathrm{E}\left(\mathrm{a}_{2}, \mathrm{a}_{3}\right)_{\text {available }}=\left\{\mathrm{E}_{8}, \mathrm{E}_{15}, \mathrm{E}_{16}\right\}$

$\mathrm{E}\left(\mathrm{a}_{2}, \mathrm{a}_{3}\right)_{\text {pavailable }}=\left\{\mathrm{E}_{6}, \mathrm{E}_{7}, \mathrm{E}_{9}, \mathrm{E}_{10}, \mathrm{E}_{13}, \mathrm{E}_{18}, \mathrm{E}_{20}\right\}$,

$\mathrm{E}\left(\mathrm{a}_{2}, \mathrm{a}_{3}\right)_{\text {navailable }}=\left\{\mathrm{E}_{5}, \mathrm{E}_{11}, \mathrm{E}_{14}\right\} \quad \mathrm{E}\left(\mathrm{a}_{2}, \mathrm{a}_{4}\right)_{\text {available }}$ $=\left\{\mathrm{E}_{8}, \mathrm{E}_{15}, \mathrm{E}_{16}\right\}$

$\mathrm{E}\left(\mathrm{a}_{2}, \mathrm{a}_{4}\right)_{\text {pavailable }}=\left\{\mathrm{E}_{6}, \mathrm{E}_{7}, \mathrm{E}_{10}, \mathrm{E}_{13}\right\} \quad \mathrm{E}\left(\mathrm{a}_{2}, \mathrm{a}_{4}\right)_{\text {navailable }}$ $=\left\{\mathrm{E}_{5}, \mathrm{E}_{11}, \mathrm{E}_{14}\right\} \quad \mathrm{E}\left(\mathrm{a}_{2}, \mathrm{a}_{5}\right)_{\text {available }}=\left\{\mathrm{E}_{8}, \mathrm{E}_{16}\right\}$ $\mathrm{E}\left(\mathrm{a}_{2}, \mathrm{a}_{5}\right)_{\text {pavailable }}=\left\{\mathrm{E}_{7}\right\}$

$\mathrm{E}\left(\mathrm{a}_{2}, \mathrm{a}_{5}\right)_{\text {navailable }}=\left\{\mathrm{E}_{11}, \mathrm{E}_{14}, \mathrm{E}_{17}\right\}$

$\mathrm{E}\left(\mathrm{a}_{3}, \mathrm{a}_{4}\right)_{\text {available }} \quad=\left\{\mathrm{E}_{1}, \mathrm{E}_{8}, \mathrm{E}_{15}, \mathrm{E}_{16}\right\}$ $\mathrm{E}\left(\mathrm{a}_{3}, \mathrm{a}_{4}\right)_{\text {pavailable }}=\left\{\mathrm{E}_{6}, \mathrm{E}_{7}, \mathrm{E}_{110}, \mathrm{E}_{13}, \mathrm{E}_{17}\right\}$

$\mathrm{E}\left(\mathrm{a}_{3}, \mathrm{a}_{4}\right)_{\text {navailable }}=\left\{\mathrm{E}_{5}, \quad \mathrm{E}_{11}, \mathrm{E}_{14}\right\} \quad \mathrm{E}\left(\mathrm{a}_{3}, \mathrm{a}_{5}\right)_{\text {available }}=\left\{\mathrm{E}_{1}\right.$, $\left.\mathrm{E}_{8}, \mathrm{E}_{15}, \mathrm{E}_{16}, \mathrm{E}_{19}\right\}$

$\mathrm{E}\left(\mathrm{a}_{3}, \mathrm{a}_{5}\right)_{\text {pavailable }}=\left\{\mathrm{E}_{6}, \mathrm{E}_{7}, \mathrm{E}_{10}, \mathrm{E}_{18} \quad\right\} \quad \mathrm{E}\left(\mathrm{a}_{3}, \mathrm{a}_{5}\right)_{\text {navailable }}$ $=\left\{\mathrm{E}_{11}, \mathrm{E}_{14}\right\}$

$\mathrm{E}\left(\mathrm{a}_{4}, \mathrm{a}_{5}\right)_{\text {available }}=\left\{\mathrm{E}_{1}, \mathrm{E}_{8}, \mathrm{E}_{15}, \mathrm{E}_{16}\right\} \mathrm{E}\left(\mathrm{a}_{4}, \mathrm{a}_{5}\right)_{\text {pavailable }}=\left\{\mathrm{E}_{6}\right.$, $\left.\mathrm{E}_{7}, \mathrm{E}_{10}\right\} \mathrm{E}\left(\mathrm{a}_{4}, \mathrm{a}_{5}\right)_{\text {navailable }}=\left\{\mathrm{E}_{2}, \mathrm{E}_{9}, \mathrm{E}_{20}\right\}$

$\mathrm{E}\left(\mathrm{a}_{1}, \mathrm{a}_{2} \quad, \mathrm{a}_{3}\right)_{\text {available }}=\left\{\mathrm{E}_{8}, \mathrm{E}_{16}\right\} \quad \mathrm{E}\left(\mathrm{a}_{1}, \mathrm{a}_{2} \quad, \mathrm{a}_{3}\right)_{\text {pavailable }}$ $=\left\{\mathrm{E}_{7}, \mathrm{E}_{20}\right\}$

$\mathrm{E}\left(\mathrm{a}_{1}, \mathrm{a}_{2}, \mathrm{a}_{3}\right)_{\text {navailable }}=\left\{\mathrm{E}_{5}, \mathrm{E}_{14}\right\}$

$\mathrm{E}\left(\mathrm{a}_{2}, \mathrm{a}_{3}, \mathrm{a}_{4}\right)_{\text {available }}=\left\{\mathrm{E}_{8}, \mathrm{E}_{15}, \mathrm{E}_{16}\right\}$

$\mathrm{E}\left(\mathrm{a}_{2}, \mathrm{a}_{3}, \mathrm{a}_{4}\right)_{\text {pavailable }}=\left\{\mathrm{E}_{6}, \mathrm{E}_{7}, \mathrm{E}_{10}, \mathrm{E}_{13}\right\}$

$\mathrm{E}\left(\mathrm{a}_{2}, \mathrm{a}_{3}, \mathrm{a}_{4}\right)_{\text {navailable }}=\left\{\mathrm{E}_{5}, \mathrm{E}_{11}, \mathrm{E}_{14}\right\} \mathrm{E}\left(\mathrm{a}_{3}, \mathrm{a}_{4}, \mathrm{a}_{5}\right)_{\text {available }}$ $=\left\{\mathrm{E}_{1}, \mathrm{E}_{8}, \mathrm{E}_{15}\right\} \quad \mathrm{E}\left(\mathrm{a}_{3}, \mathrm{a}_{4}, \mathrm{a}_{5}\right)_{\text {pavailable }}=\left\{\mathrm{E}_{6}, \mathrm{E}_{7}, \mathrm{E}_{10}\right\}$ $\mathrm{E}\left(\mathrm{a}_{3}, \mathrm{a}_{4}, \mathrm{a}_{5}\right)_{\text {navailable }}=\left\{\mathrm{E}_{11}, \mathrm{E}_{14}\right\}$

$\mathrm{E}\left(\mathrm{a}_{1}, \mathrm{a}_{2}, \mathrm{a}_{3}, \mathrm{a}_{4}\right)_{\text {available }}=\left\{\mathrm{E}_{8}, \mathrm{E}_{16}\right\}$

$\mathrm{E}\left(\mathrm{a}_{1}, \mathrm{a}_{2}, \mathrm{a}_{3}, \mathrm{a}_{4}\right)_{\text {pavailable }}=\left\{\mathrm{E}_{7}\right\}$

$\mathrm{E}\left(\mathrm{a}_{1}, \mathrm{a}_{2}, \mathrm{a}_{3}, \mathrm{a}_{4}\right)_{\text {navailable }}=\left\{\mathrm{E}_{5}, \mathrm{E}_{14}\right\}$ these equivalence classes are basically responsible for finding the dependencies with respect to the decision variable $\mathrm{d}$ in this paper besides all equivalence classes, we are trying to find out the degree of dependencies of different attributes of consideration with respect to decision attributes $d$ considering only attribute print media that is $\mathrm{E}\left(\mathrm{a}_{1}\right)_{\text {available/pavailable }}$ (success) or(failure)) cases can't classified as several ambiguity result found out that is $\left\{\mathrm{E}_{2}, \mathrm{E}_{5}\right\},\left\{\mathrm{E}_{9}, \mathrm{E}_{10}\right\},\left\{\mathrm{E}_{12}, \mathrm{E}_{3}\right\},\left\{\mathrm{E}_{14}, \mathrm{E}_{15}\right\},\left\{\mathrm{E}_{16}, \mathrm{E}_{17}\right\}$ with respect to decision variable $\mathrm{d}$ so for that urban 
location gives insignificant result so this attribute has hardly any importance. similarly for five star accommodation we have to find the degree of dependency (five star accommodation as $\mathrm{a}_{2}$ ) $\mathrm{E}\left(\mathrm{a}_{2}\right)_{\text {available/pavailable }}($ success $)=\quad\left\{\mathrm{E}_{1}, \mathrm{E}_{2}, \mathrm{E}_{6}, \mathrm{E}_{7}, \mathrm{E}_{9}, \mathrm{E}_{12}, \quad \mathrm{E}_{8}\right.$, $\left.\mathrm{E}_{15}, \mathrm{E}_{16}, \mathrm{E}_{20}\right\}$ so degree of dependency $10 / 20$ for the success cases with respect to decision variable $\mathrm{d}$ similarly the failure cases in five star accommodation cases are $\mathrm{E}\left(\mathrm{a}_{2}\right)_{\text {pvailable }} \quad$ (sucess) $=\left\{\quad \mathrm{E}_{8}, \quad \mathrm{E}_{15}, \mathrm{E}_{16}, \mathrm{E}_{20}\right\} \quad 4 / 20$ $\mathrm{E}\left(\mathrm{a}_{2}\right)_{\text {available }}($ failure $)=\left\{\mathrm{E}_{17}, \mathrm{E}_{18}, \mathrm{E}_{19}\right\} \quad 3 / 20$ for that we can have a significant result for five stars accommodation is available, partially available, not available is in general has certain degree of significance in business success that is if five star accommodation for a particular location is available leads to a positive or a successful result. Upon analyzing city with aviation facilities we have the following results $E\left(a_{3}\right)$ available/pavailable (success)

$=\left\{\mathrm{E}_{1}, \mathrm{E}_{2}, \mathrm{E}_{6} \mathrm{E}_{7}, \mathrm{E}_{8}, \mathrm{E}_{9} \mathrm{E}_{12}, \mathrm{E}_{15}, \mathrm{E}_{20}\right\} \quad \mathrm{E}_{16}, \mathrm{E}_{19}$ Produces ambiguous result so here the degree dependency $9 / 20$ on success cases two ambiguous cases similarly the negative cases $\quad \mathrm{E}\left(\mathrm{a}_{3}\right)$ (negative) $)_{\text {available/pavailable }}=\left\{\mathrm{E}_{10}, \mathrm{E}_{11}\right.$, $\left.\mathrm{E}_{13}, \mathrm{E}_{14}, \mathrm{E}_{17}, \mathrm{E}_{18}, \mathrm{E}_{19}\right\}$ That is the degree of dependency will be 7/20 but in analyzing the data we have the cases like $\mathrm{E}_{1}, \mathrm{E}_{2}, \mathrm{E}_{8}, \mathrm{E}_{12}$ produces the same result that is if aviation facilities is available or partially available in nature is moderate then we have success cases similarly analyzing the negative cases we have similar result $\mathrm{E}_{5}, \mathrm{E}_{6}$ produces ambiguous result so we are consider these and for other cases $\mathrm{E}_{10}, \mathrm{E}_{13}, \mathrm{E}_{14}, \mathrm{E}_{17}, \mathrm{E}_{18}$ produces the same result that is all high localize produces failure result , that if localize is high the still business failure is being observed so upon analyzing the data, location where aviation facilities are available produces insignificant result that is in some cases this attribute produce success and in some cases it deliver negative result the number in both cases are nearly equal .So for that in case of the business cities where aviation facilities are available does not provide any information from which we cannot generate any definite rule from the city where aviation facilities are available attribute dropping this attribute from the decision table may hamper the investigation process so we keep this attribute in the decision table for further investigation next we investigate

$\mathrm{E}\left(\mathrm{a}_{4}\right)_{\text {pavailable/available }}$ (success $)=\left\{\mathrm{E}_{1}, \mathrm{E}_{6}, \quad \mathrm{E}_{7}, \mathrm{E}_{12}, \mathrm{E}_{15}, \mathrm{E}_{16}\right\}$ dependency factor for positive cases will be $6 / 20$

$\mathrm{E}\left(\mathrm{a}_{4}\right)_{\text {pavailable }} /$ available $\quad$ (failure) $=\left\{\mathrm{E}_{5}, \mathrm{E}_{11}, \quad \mathrm{E}_{14}, \mathrm{E}_{18}\right\} \quad \mathrm{E}_{19}, \mathrm{E}_{20}$ gives ambiguous result here dependency factor for negative cases will be $4 / 20$ similarly for analyzing indirect advertisement we have $\mathrm{E}\left(\mathrm{a}_{5}\right)$ available/p available (success) $=\left\{\mathrm{E}_{1}, \mathrm{E}_{6}, \mathrm{E}_{15}\right\}$ two ambiguity result $\mathrm{E}_{8}, \mathrm{E}_{13}$ and $\mathrm{E}_{12}, \mathrm{E}_{18}$ in failure cases similarly in negative cases $\mathrm{E}_{5}, \mathrm{E}_{7}$ are ambiguous result so need not go for further investigation so we can drop two attributes from the tables that is $a_{1}, a_{5}$ from the table so we are having new table given below. We are considering the definite cases whether failure or success for the cases where we are not sure of the result we keep those attribute in the table for further investigation, the reduct table which we generate presented in Table- 3

\section{Table-3}

\begin{tabular}{|l|l|l|l|l|}
\hline$E$ & $a_{2}$ & $a_{3}$ & $a_{4}$ & $d$ \\
\hline$E_{1}$ & $b_{2}$ & $b_{1}$ & $b_{1}$ & $c_{1}$ \\
\hline$E_{2}$ & $b_{2}$ & $b_{1}$ & $b_{3}$ & $c_{1}$ \\
\hline$E_{5}$ & $b_{1}$ & $b_{2}$ & $b_{3}$ & $c_{2}$ \\
\hline$E_{6}$ & $b_{2}$ & $b_{2}$ & $b_{2}$ & $c_{1}$ \\
\hline$E_{7}$ & $b_{2}$ & $b_{2}$ & $b_{2}$ & $c_{1}$ \\
\hline$E_{8}$ & $b_{1}$ & $b_{1}$ & $b_{1}$ & $c_{1}$ \\
\hline$E_{9}$ & $b_{2}$ & $b_{2}$ & $b_{3}$ & $c_{1}$ \\
\hline$E_{10}$ & $b_{2}$ & $b_{2}$ & $b_{2}$ & $c_{2}$ \\
\hline$E_{11}$ & $b_{2}$ & $b_{1}$ & $b_{3}$ & $c_{2}$ \\
\hline$E_{12}$ & $b_{2}$ & $b_{1}$ & $b_{1}$ & $c_{1}$ \\
\hline$E_{13}$ & $b_{2}$ & $b_{2}$ & $b_{2}$ & $c_{2}$ \\
\hline$E_{14}$ & $b_{2}$ & $b_{2}$ & $b_{3}$ & $c_{2}$ \\
\hline$E_{15}$ & $b_{1}$ & $b_{1}$ & $b_{1}$ & $c_{1}$ \\
\hline$E_{16}$ & $b_{1}$ & $b_{1}$ & $b_{1}$ & $c_{1}$ \\
\hline$E_{17}$ & $b_{2}$ & $b_{2}$ & $b_{2}$ & $c_{2}$ \\
\hline$E_{18}$ & $b_{2}$ & $b_{2}$ & $b_{3}$ & $c_{2}$ \\
\hline$E_{19}$ & $b_{2}$ & $b_{1}$ & $b_{3}$ & $c_{2}$ \\
\hline$E_{20}$ & $b_{1}$ & $b_{2}$ & $b_{3}$ & $c_{1}$ \\
\hline
\end{tabular}

In table 3 we found $\mathrm{E}_{1}, \mathrm{E}_{12}$ provides same values similarly $\mathrm{E}_{6}, \mathrm{E}_{7}$ also provide the same result and $\mathrm{E}_{2}, \mathrm{E}_{11}$ ambiguous result so we keep one table $\mathrm{E}_{1}$ for $\mathrm{E}_{1}, \mathrm{E}_{12}$ and keep $\mathrm{E}_{6}$ for $\mathrm{E}_{6}, \mathrm{E}_{7}$ and drop both $\mathrm{E}_{2}, \mathrm{E}_{11}$ from the tables to leads to table 4

Table 4

\begin{tabular}{|l|l|l|l|l|}
\hline $\mathrm{E}$ & $\mathrm{a}_{2}$ & $\mathrm{a}_{3}$ & $\mathrm{a}_{4}$ & $\mathrm{~d}$ \\
\hline $\mathrm{E}_{1}$ & $\mathrm{~b}_{2}$ & $\mathrm{~b}_{1}$ & $\mathrm{~b}_{1}$ & $\mathrm{c}_{1}$ \\
\hline $\mathrm{E}_{5}$ & $\mathrm{~b}_{1}$ & $\mathrm{~b}_{2}$ & $\mathrm{~b}_{3}$ & $\mathrm{c}_{2}$ \\
\hline $\mathrm{E}_{6}$ & $\mathrm{~b}_{2}$ & $\mathrm{~b}_{2}$ & $\mathrm{~b}_{2}$ & $\mathrm{c}_{1}$ \\
\hline $\mathrm{E}_{8}$ & $\mathrm{~b}_{1}$ & $\mathrm{~b}_{1}$ & $\mathrm{~b}_{1}$ & $\mathrm{c}_{1}$ \\
\hline $\mathrm{E}_{9}$ & $\mathrm{~b}_{2}$ & $\mathrm{~b}_{2}$ & $\mathrm{~b}_{3}$ & $\mathrm{c}_{1}$ \\
\hline $\begin{array}{l}\mathrm{E}_{1} \\
0\end{array}$ & $\mathrm{~b}_{2}$ & $\mathrm{~b}_{2}$ & $\mathrm{~b}_{2}$ & $\mathrm{c}_{2}$ \\
\hline $\mathrm{E}_{1}$ & $\mathrm{~b}_{2}$ & $\mathrm{~b}_{2}$ & $\mathrm{~b}_{2}$ & $\mathrm{c}_{2}$ \\
\hline
\end{tabular}




\begin{tabular}{|l|l|l|l|l|}
\hline 3 & & & & \\
\hline $\begin{array}{l}\mathrm{E}_{1} \\
4\end{array}$ & $\mathrm{~b}_{2}$ & $\mathrm{~b}_{2}$ & $\mathrm{~b}_{3}$ & $\mathrm{c}_{2}$ \\
\hline $\begin{array}{l}\mathrm{E}_{1} \\
5\end{array}$ & $\mathrm{~b}_{1}$ & $\mathrm{~b}_{1}$ & $\mathrm{~b}_{1}$ & $\mathrm{c}_{1}$ \\
\hline $\begin{array}{l}\mathrm{E}_{1} \\
6\end{array}$ & $\mathrm{~b}_{1}$ & $\mathrm{~b}_{1}$ & $\mathrm{~b}_{1}$ & $\mathrm{c}_{1}$ \\
\hline $\begin{array}{l}\mathrm{E}_{1} \\
7\end{array}$ & $\mathrm{~b}_{2}$ & $\mathrm{~b}_{2}$ & $\mathrm{~b}_{2}$ & $\mathrm{c}_{2}$ \\
\hline $\begin{array}{l}\mathrm{E}_{1} \\
8\end{array}$ & $\mathrm{~b}_{2}$ & $\mathrm{~b}_{2}$ & $\mathrm{~b}_{3}$ & $\mathrm{c}_{2}$ \\
\hline $\begin{array}{l}\mathrm{E}_{1} \\
9\end{array}$ & $\mathrm{~b}_{2}$ & $\mathrm{~b}_{1}$ & $\mathrm{~b}_{3}$ & $\mathrm{c}_{2}$ \\
\hline $\begin{array}{l}\mathrm{E}_{2} \\
0\end{array}$ & $\mathrm{~b}_{1}$ & $\mathrm{~b}_{2}$ & $\mathrm{~b}_{3}$ & $\mathrm{c}_{1}$ \\
\hline
\end{tabular}

From the table- 4 we get conclusion that E5,E20 provides ambiguous result so we drop both E5,E20 from the table leads to table table-5

\section{Table-5}

\begin{tabular}{|l|l|l|l|l|}
\hline $\mathrm{E}$ & $\mathrm{a}_{2}$ & $\mathrm{a}_{3}$ & $\mathrm{a}_{4}$ & $\mathrm{~d}$ \\
\hline $\mathrm{E}_{1}$ & $\mathrm{~b}_{2}$ & $\mathrm{~b}_{1}$ & $\mathrm{~b}_{1}$ & $\mathrm{c}_{1}$ \\
\hline $\mathrm{E}_{6}$ & $\mathrm{~b}_{2}$ & $\mathrm{~b}_{2}$ & $\mathrm{~b}_{2}$ & $\mathrm{c}_{1}$ \\
\hline $\mathrm{E}_{8}$ & $\mathrm{~b}_{1}$ & $\mathrm{~b}_{1}$ & $\mathrm{~b}_{1}$ & $\mathrm{c}_{1}$ \\
\hline $\mathrm{E}_{9}$ & $\mathrm{~b}_{2}$ & $\mathrm{~b}_{2}$ & $\mathrm{~b}_{3}$ & $\mathrm{c}_{1}$ \\
\hline $\begin{array}{l}\mathrm{E}_{1} \\
0\end{array}$ & $\mathrm{~b}_{2}$ & $\mathrm{~b}_{2}$ & $\mathrm{~b}_{2}$ & $\mathrm{c}_{2}$ \\
\hline $\begin{array}{l}\mathrm{E}_{1} \\
3\end{array}$ & $\mathrm{~b}_{2}$ & $\mathrm{~b}_{2}$ & $\mathrm{~b}_{2}$ & $\mathrm{c}_{2}$ \\
\hline $\begin{array}{l}\mathrm{E}_{1} \\
4\end{array}$ & $\mathrm{~b}_{2}$ & $\mathrm{~b}_{2}$ & $\mathrm{~b}_{3}$ & $\mathrm{c}_{2}$ \\
\hline $\begin{array}{l}\mathrm{E}_{1} \\
5\end{array}$ & $\mathrm{~b}_{1}$ & $\mathrm{~b}_{1}$ & $\mathrm{~b}_{1}$ & $\mathrm{c}_{1}$ \\
\hline $\begin{array}{l}\mathrm{E}_{1} \\
6\end{array}$ & $\mathrm{~b}_{1}$ & $\mathrm{~b}_{1}$ & $\mathrm{~b}_{1}$ & $\mathrm{c}_{1}$ \\
\hline $\begin{array}{l}\mathrm{E}_{1} \\
7\end{array}$ & $\mathrm{~b}_{2}$ & $\mathrm{~b}_{2}$ & $\mathrm{~b}_{2}$ & $\mathrm{c}_{2}$ \\
\hline $\begin{array}{l}\mathrm{E}_{1} \\
8\end{array}$ & $\mathrm{~b}_{2}$ & $\mathrm{~b}_{2}$ & $\mathrm{~b}_{3}$ & $\mathrm{c}_{2}$ \\
\hline $\begin{array}{l}\mathrm{E}_{1} \\
9\end{array}$ & $\mathrm{~b}_{2}$ & $\mathrm{~b}_{1}$ & $\mathrm{~b}_{3}$ & $\mathrm{c}_{2}$ \\
\hline
\end{tabular}

Again analyzing table -5 we have E6,E10 produces ambiguous result and

$\left\{\mathrm{E}_{13}, \mathrm{E}_{17}\right.$ \}leads to single results that is $\mathrm{E}_{13}$ so table -5 further reduces to table -6 by deleting the ambiguity and redundancy

\section{Table-6}

\begin{tabular}{|l|l|l|l|l|}
\hline $\mathrm{E}$ & $\mathrm{a}_{2}$ & $\mathrm{a}_{3}$ & $\mathrm{a}_{4}$ & $\mathrm{~d}$ \\
\hline $\mathrm{E}_{1}$ & $\mathrm{~b}_{2}$ & $\mathrm{~b}_{1}$ & $\mathrm{~b}_{1}$ & $\mathrm{c}_{1}$ \\
\hline $\mathrm{E}_{8}$ & $\mathrm{~b}_{1}$ & $\mathrm{~b}_{1}$ & $\mathrm{~b}_{1}$ & $\mathrm{c}_{1}$ \\
\hline $\mathrm{E}_{9}$ & $\mathrm{~b}_{2}$ & $\mathrm{~b}_{2}$ & $\mathrm{~b}_{3}$ & $\mathrm{c}_{1}$ \\
\hline $\begin{array}{l}\mathrm{E}_{1} \\
3\end{array}$ & $\mathrm{~b}_{2}$ & $\mathrm{~b}_{2}$ & $\mathrm{~b}_{2}$ & $\mathrm{c}_{2}$ \\
\hline $\begin{array}{l}\mathrm{E}_{1} \\
4\end{array}$ & $\mathrm{~b}_{2}$ & $\mathrm{~b}_{2}$ & $\mathrm{~b}_{3}$ & $\mathrm{c}_{2}$ \\
\hline $\begin{array}{l}\mathrm{E}_{1} \\
5\end{array}$ & $\mathrm{~b}_{1}$ & $\mathrm{~b}_{1}$ & $\mathrm{~b}_{1}$ & $\mathrm{c}_{1}$ \\
\hline $\begin{array}{l}\mathrm{E}_{1} \\
6\end{array}$ & $\mathrm{~b}_{1}$ & $\mathrm{~b}_{1}$ & $\mathrm{~b}_{1}$ & $\mathrm{c}_{1}$ \\
\hline $\begin{array}{l}\mathrm{E}_{1} \\
8\end{array}$ & $\mathrm{~b}_{2}$ & $\mathrm{~b}_{2}$ & $\mathrm{~b}_{3}$ & $\mathrm{c}_{2}$ \\
\hline $\begin{array}{l}\mathrm{E}_{1} \\
9\end{array}$ & $\mathrm{~b}_{2}$ & $\mathrm{~b}_{1}$ & $\mathrm{~b}_{3}$ & $\mathrm{c}_{2}$ \\
\hline
\end{tabular}

Now further classification $\mathrm{E}_{15}, \mathrm{E}_{16}$ leads to same class that is $\left\{\mathrm{E}_{15}, \mathrm{E}_{16}\right\}=\mathrm{E}_{15}$ further reduction produces table-7 by deleting the redundant rows.

Table-7

\begin{tabular}{|l|l|l|l|l|}
\hline $\mathrm{E}$ & $\mathrm{a}_{2}$ & $\mathrm{a}_{3}$ & $\mathrm{a}_{4}$ & $\mathrm{~d}$ \\
\hline $\mathrm{E}_{1}$ & $\mathrm{~b}_{2}$ & $\mathrm{~b}_{1}$ & $\mathrm{~b}_{1}$ & $\mathrm{c}_{1}$ \\
\hline $\mathrm{E}_{8}$ & $\mathrm{~b}_{1}$ & $\mathrm{~b}_{1}$ & $\mathrm{~b}_{1}$ & $\mathrm{c}_{1}$ \\
\hline $\mathrm{E}_{9}$ & $\mathrm{~b}_{2}$ & $\mathrm{~b}_{2}$ & $\mathrm{~b}_{3}$ & $\mathrm{c}_{1}$ \\
\hline $\begin{array}{l}\mathrm{E}_{1} \\
3\end{array}$ & $\mathrm{~b}_{2}$ & $\mathrm{~b}_{2}$ & $\mathrm{~b}_{2}$ & $\mathrm{c}_{2}$ \\
\hline $\begin{array}{l}\mathrm{E}_{1} \\
4\end{array}$ & $\mathrm{~b}_{2}$ & $\mathrm{~b}_{2}$ & $\mathrm{~b}_{3}$ & $\mathrm{c}_{2}$ \\
\hline $\begin{array}{l}\mathrm{E}_{1} \\
5\end{array}$ & $\mathrm{~b}_{1}$ & $\mathrm{~b}_{1}$ & $\mathrm{~b}_{1}$ & $\mathrm{c}_{1}$ \\
\hline $\begin{array}{l}\mathrm{E}_{1} \\
8\end{array}$ & $\mathrm{~b}_{2}$ & $\mathrm{~b}_{2}$ & $\mathrm{~b}_{3}$ & $\mathrm{c}_{2}$ \\
\hline $\begin{array}{l}\mathrm{E}_{1} \\
9\end{array}$ & $\mathrm{~b}_{2}$ & $\mathrm{~b}_{1}$ & $\mathrm{~b}_{3}$ & $\mathrm{c}_{2}$ \\
\hline
\end{tabular}

Continuing the reduction process we further reduces $\mathrm{E}_{14}, \mathrm{E}_{18}$ giving the same conclusion both leads to same result which generate the reduction table as table- 8

Table-8

\begin{tabular}{|l|l|l|l|l|}
\hline $\mathrm{E}$ & $\mathrm{a}_{2}$ & $\mathrm{a}_{3}$ & $\mathrm{a}_{4}$ & $\mathrm{~d}$ \\
\hline $\mathrm{E}_{1}$ & $\mathrm{~b}_{2}$ & $\mathrm{~b}_{1}$ & $\mathrm{~b}_{1}$ & $\mathrm{c}_{1}$ \\
\hline $\mathrm{E}_{8}$ & $\mathrm{~b}_{1}$ & $\mathrm{~b}_{1}$ & $\mathrm{~b}_{1}$ & $\mathrm{c}_{1}$ \\
\hline $\mathrm{E}_{9}$ & $\mathrm{~b}_{2}$ & $\mathrm{~b}_{2}$ & $\mathrm{~b}_{3}$ & $\mathrm{c}_{1}$ \\
\hline
\end{tabular}




\begin{tabular}{|l|l|l|l|l|}
\hline $\begin{array}{l}\mathrm{E}_{1} \\
3\end{array}$ & $\mathrm{~b}_{2}$ & $\mathrm{~b}_{2}$ & $\mathrm{~b}_{2}$ & $\mathrm{c}_{2}$ \\
\hline $\begin{array}{l}\mathrm{E}_{1} \\
4\end{array}$ & $\mathrm{~b}_{2}$ & $\mathrm{~b}_{2}$ & $\mathrm{~b}_{3}$ & $\mathrm{c}_{2}$ \\
\hline $\begin{array}{l}\mathrm{E}_{1} \\
5\end{array}$ & $\mathrm{~b}_{1}$ & $\mathrm{~b}_{1}$ & $\mathrm{~b}_{1}$ & $\mathrm{c}_{1}$ \\
\hline $\begin{array}{l}\mathrm{E}_{1} \\
9\end{array}$ & $\mathrm{~b}_{2}$ & $\mathrm{~b}_{1}$ & $\mathrm{~b}_{3}$ & $\mathrm{c}_{2}$ \\
\hline
\end{tabular}

The same procedure again gives us further reduction that is $\mathrm{E}_{8}, \mathrm{E}_{15}$ also leads to same information sets so further reduction gives another tale named as table- 9

Table-9

\begin{tabular}{|l|l|l|l|l|}
\hline $\mathrm{E}$ & $\mathrm{a}_{2}$ & $\mathrm{a}_{3}$ & $\mathrm{a}_{4}$ & $\mathrm{~d}$ \\
\hline $\mathrm{E}_{1}$ & $\mathrm{~b}_{2}$ & $\mathrm{~b}_{1}$ & $\mathrm{~b}_{1}$ & $\mathrm{c}_{1}$ \\
\hline $\mathrm{E}_{8}$ & $\mathrm{~b}_{1}$ & $\mathrm{~b}_{1}$ & $\mathrm{~b}_{1}$ & $\mathrm{c}_{1}$ \\
\hline $\mathrm{E}_{9}$ & $\mathrm{~b}_{2}$ & $\mathrm{~b}_{2}$ & $\mathrm{~b}_{3}$ & $\mathrm{c}_{1}$ \\
\hline $\begin{array}{l}\mathrm{E}_{1} \\
3\end{array}$ & $\mathrm{~b}_{2}$ & $\mathrm{~b}_{2}$ & $\mathrm{~b}_{2}$ & $\mathrm{c}_{2}$ \\
\hline $\begin{array}{l}\mathrm{E}_{1} \\
4\end{array}$ & $\mathrm{~b}_{2}$ & $\mathrm{~b}_{2}$ & $\mathrm{~b}_{3}$ & $\mathrm{c}_{2}$ \\
\hline $\begin{array}{l}\mathrm{E}_{1} \\
9\end{array}$ & $\mathrm{~b}_{2}$ & $\mathrm{~b}_{1}$ & $\mathrm{~b}_{3}$ & $\mathrm{c}_{2}$ \\
\hline
\end{tabular}

Here in table -9 again we have $\mathrm{E}_{9}, \mathrm{E}_{14}$ leads to ambiguous results so dropping both the table for further classification we have table- 10 .

Table-10

\begin{tabular}{|l|l|l|l|l|}
\hline $\mathrm{E}$ & $\mathrm{a}_{2}$ & $\mathrm{a}_{3}$ & $\mathrm{a}_{4}$ & $\mathrm{~d}$ \\
\hline $\mathrm{E}_{1}$ & $\mathrm{~b}_{2}$ & $\mathrm{~b}_{1}$ & $\mathrm{~b}_{1}$ & $\mathrm{c}_{1}$ \\
\hline $\mathrm{E}_{8}$ & $\mathrm{~b}_{1}$ & $\mathrm{~b}_{1}$ & $\mathrm{~b}_{1}$ & $\mathrm{c}_{1}$ \\
\hline $\mathrm{E}_{9}$ & $\mathrm{~b}_{2}$ & $\mathrm{~b}_{2}$ & $\mathrm{~b}_{3}$ & $\mathrm{c}_{1}$ \\
\hline $\begin{array}{l}\mathrm{E}_{1} \\
3\end{array}$ & $\mathrm{~b}_{2}$ & $\mathrm{~b}_{2}$ & $\mathrm{~b}_{2}$ & $\mathrm{c}_{2}$ \\
\hline $\begin{array}{l}\mathrm{E}_{1} \\
9\end{array}$ & $\mathrm{~b}_{2}$ & $\mathrm{~b}_{1}$ & $\mathrm{~b}_{3}$ & $\mathrm{c}_{2}$ \\
\hline
\end{tabular}

Now next we find the strength[27] of rules for attributes $a_{2}$, $a_{3}, a_{4}$ strength of rules for attributes define as strength for an association rule $\mathrm{x} \rightarrow \mathrm{D}$ define as is the number of examples that contain xUD to the number examples that contains $\mathrm{x}$

$\left(\mathrm{a}_{2}=\mathrm{b}_{2}\right) \rightarrow\left(\mathrm{d}=\mathrm{c}_{1}\right)=2 / 3=66 \%$

$,\left(\mathrm{a}_{2}=\mathrm{b}_{1}\right) \rightarrow\left(\mathrm{d}=\mathrm{c}_{1}\right)=1=100 \%,\left(\mathrm{a}_{2}=\mathrm{b}_{2}\right) \rightarrow\left(\mathrm{d}=\mathrm{c}_{2}\right)=2 / 4=25 \%$,

$\left(\mathrm{a}_{2}=\mathrm{b}_{1}\right) \rightarrow\left(\mathrm{d}=\mathrm{c}_{2}\right)=$ nil now we calculate strength for $\mathrm{a}_{3}$ $\left(\mathrm{a}_{3}=\mathrm{b}_{1}\right) \rightarrow\left(\mathrm{d}=\mathrm{c}_{1}\right)=2 / 3=66 \%,\left(\mathrm{a}_{3}=\mathrm{b}_{2}\right) \rightarrow\left(\mathrm{d}=\mathrm{c}_{1}\right)=1 / 2=50 \%,\left(\mathrm{a}_{3}=\mathrm{b}\right.$ 1) $\rightarrow\left(\mathrm{d}=\mathrm{c}_{2}\right)=1 / 3=33 \%$,

$\left(\mathrm{a}_{3}=\mathrm{b}_{2}\right) \rightarrow\left(\mathrm{d}=\mathrm{c}_{2}\right)=1 / 2=50$
Similarly strength for $\mathrm{a}_{4}$ will be $\left(\mathrm{a}_{4}=\mathrm{b}_{1}\right) \rightarrow\left(\mathrm{d}=\mathrm{c}_{1}\right)=1=100 \%$ $\left(\mathrm{a}_{4}=\mathrm{b}_{2}\right) \rightarrow\left(\mathrm{d}=\mathrm{c}_{1}\right)=1=100 \%,\left(\mathrm{a}_{4}=\mathrm{b}_{1}\right) \rightarrow\left(\mathrm{d}=\mathrm{c}_{2}\right)=$ nil

$\left(\mathrm{a}_{4}=\mathrm{b}_{3}\right) \rightarrow\left(\mathrm{d}=\mathrm{c}_{2}\right)=1 / 2=50 \%,\left(\mathrm{a}_{4}=\mathrm{b}_{2}\right) \rightarrow\left(\mathrm{d}=\mathrm{c}_{2}\right)=100 \%$

In this analysis we find a 2 and a 3 must important attributes in analyzing the data analysis as because we are having a result for a4 that is available gives a failure result so the conditional attribute a4 is not that important like a2, a3 from the above analysis we develop a rule that is

Rule

1.(a2) available/p available shows a success that is a2 is $\mathrm{p}$ available or available leads to business success similarly

2.For (a3 ) available/p available $\rightarrow$ may leads to a business success but still there is a $50 \%$ chances of failure also exit in location with aviation facilities . The result what we get from the experiment gives one result that is a location may have both aviation and five stars facilities gives us in significant result.

\subsection{Statistical validation}

We basically focus on small scale industries and business establishment with small investment, although we get a conclusion. As rough set deals with uncertainty may leads to some kind of confusion regarding the result to validate our claims we depends upon chi squared test to validate our claim by using chi squared test

We found that chi squared value that is chi squared value we consider as $\mathrm{k}$ which lies below the critical range

\subsection{Experimental section}

We take survey of different successful business organization adopting the rule generated by rough set principle are as follows

Expected $15 \%, 10 \%, 15 \%, 20 \%, 30 \%, 15 \%$ and the Observed samples are $25,14,3445,62,20$ so totaling these we have total of 200 samples so expected numbers of samples per each day as follows $30,20,30,40,60,30$. We then apply chi square distribution to verify our result assuming that $\mathrm{H}_{0}$ is our hypothesis that is correct $\mathrm{H}_{1}$ as alternate hypothesis that is not correct , Then we expect sample in six cases as

chi squared estimation formula is $\sum\left(\mathrm{O}_{\mathrm{i}}-\mathrm{E}_{\mathrm{i}}\right)^{2} / \mathrm{E}_{\mathrm{i}}$ where $\mathrm{i}=0,1,2,3,4,5$ so the calculated as follows $\mathrm{X}^{2}=(25$ $30)^{2} / 20+(14-20)^{2} / 20+(34-30)^{2} / 30+(45-40)^{2} / 40+(62-$ $60)^{2} / 60+(20-30)^{2} / 30$

$X^{2}=25 / 20+36 / 20+16 / 30+25 / 40+4 / 60+100 / 30=7.60 \quad$ the tabular values we have with degree of freedom 5 we get result 11.04

Our experiment result is lies quite below the tabular values, so it lies in the acceptable region. So we accept the hypothesis $\mathrm{H}_{0}$ that of our experiment result is correct.

\section{FUTURE WORK}

Our work can be extended to different fields like student feedback system, Business data analysis, Medical data analysis

\section{CONCLUSION}

This is based upon mathematical analysis and experiment which is gives some accurate result in generating rules, from a vast diversified data base. This also give a very précised result 


\section{REFERENCES}

[1] S.K. Pal, A. Skowron, Rough Fuzzy Hybridization: A new trend in decision making, Berlin, Springer-Verlag, 1999

[2] Z. Pawlak, "Rough sets", International Journal of Computer and Computer and Information Sciences, Vol. 11, 1982, pp.341-356

[3] Z. Pawlak, Rough Sets: Theoretical Aspects of Reasoning about Data, System Theory, Knowledge Engineering and Problem Solving, Vol. 9, The Netherlands, Kluwer - Academic Publishers, Dordrecht, 1991

[4] Han, Jiawei, Kamber, Micheline, Data Mining: Concepts and Techniques. San Franciso CA, USA, Morgan Kaufmann Publishers, 2001

[5] Ramakrishnan, Naren and Grama, Y. Ananth, "Data Mining: From Serendipity to Science", IEEE Computer, 1999, pp. 34-37.

[6] Williams, J. Graham, Simoff, J. Simeon, Data Mining Theory, Methodology, Techniques, and Applications (Lecture Notes in Computer Science/ Lecture Notes in Artificial Intelligence), Springer, 2006.

[7] D.J. Hand, H. Mannila, P. Smyth, Principles of Data Mining. Cambridge, MA: MIT Press, 2001

[8] D.J. Hand, G.Blunt, M.G. Kelly, N.M.Adams, "Data mining for fun and profit", Statistical Science, Vol.15, 2000, pp.111-131.

[9] C. Glymour, D. Madigan, D. Pregibon, P.Smyth, "Statistical inference and data mining", Communications of the ACM, Vol. 39, No.11,1996, pp.35-41.

[10] T.Hastie, R.Tibshirani, J.H. Friedman, Elements of statistical learning: data mining, inference and prediction, New York: Springer Verlag, 2001

[11] H.Lee, H. Ong, "Visualization support for data Mining”, IEEE Expert, Vol. 11, No. 5, 1996, pp. 6975 .

[12] H. Lu, R. Setiono, H. Liu, "Effective data Mining using neural networks", IEEE Transactions on Knowledge and Data Engineering, Vol. 8, No. 6, 1996, pp. $957-$ 961.

[13] E.I Altman, "Financial ratios, discriminants analysis and prediction of corporate bankruptcy", The journal of finance, Vol. 23 , 1968, pp.589-609

[14] E.I.Altman, R.Avery, R.Eisenbeis, J. Stnkey, "Application of classification techniques in business, banking and finance. Contemporary studies in Economic and Financial Analysis", vol.3, Greenwich, JAI Press, 1981.

[15] E.I Altman, "The success of business failure prediction models: An international surveys", Journal of Banking and Finance Vol. 8, no.2, 1984, pp.171-198

[16] E.I Altman, G. Marco, F. Varetto, "Corporate distress diagnosis: Comparison using discriminant analysis and neural networks", Journal of Banking and Finance, Vol. 18, 1994, pp. 505-529

[17] W.H Beaver, "Financial ratios as predictors of failure. Empirical Research in accounting : Selected studies", Journal of Accounting Research Supplement to Vol 4, 1966, pp.71-111

[18] J.K Courtis, "Modelling a financial ratios categoric frame Work", Journal of Business Finance and Accounting, Vol. 5, No.4, 1978, pp71-111

[19] H.Frydman, E.I Altman ,D-IKao, "Introducing recursive partitioning for financial classification: the case of financial distress", The Journal of Finance, Vol.40, No. 1, 1985, pp. 269-291.

[20] Y.P.Gupta, R.P.Rao, P.K. , Linear Goal programming as an alternative to multivariate discriminant analysis a note journal of business fiancé and accounting Vol.17, No.4, 1990, pp. 593-598

[21] M. Louma, E, K. Laitinen, "Survival analysis as a tool for company failure prediction". Omega, Vol.19, No.6, 1991, pp. 673-678

[22] W.F. Messier, J.V. Hanseen, "Including rules for expert system development: an example using default and bankruptcy data", Management Science, Vol. 34 No.12, 1988, pp.1403-1415

[23] E.M. Vermeulen, J. Spronk, N. Van der Wijst., The application of Multifactor Model in the analysis of corporate failure. In: Zopounidis,C.(Ed), Operational corporate Tools in the Management of financial Risks, Kluwer Academic Publishers, Dordrecht, 1998, pp. 59-73

[24] C. Zopounidis, A.I. Dimitras, L. Le Rudulier, A multicriteria approach for the analysis and prediction of business failure in Greece. Cahier du LAMSADE, No. 132, Universite de Paris Dauphine, 1995.

[25] C. Zopounidis, N.F. Matsatsinis, M. Doumpos, "Developing a multicriteria knowledge-based decision support system for the assessment of corporate performance and viability: The FINEVA system, "Fuzzy Economic Review, Vol. 1, No. 2, 1996, pp. 3553 .

[26] C. Zopounidis, M. Doumpos, N.F. Matsatsinis, "Application of the FINEVA multicriteria knowledgedecision support systems to the assessment of corporate failure risk", Foundations of Computing and Decision Sciences, Vol. 21, No. 4, 1996, pp. 233-251

[27] Renu Vashist Prof M.L Garg Rule Generation based on Reduct and Core :A rough set approach International Journal of Computer Application(0975887) Vol 29 September -2011 Page 1-4 